HANNA PODEDWORNA

Szkoła Główna Gospodarstwa Wiejskiego w Warszawie

Wydział Nauk Społecznych

\title{
WIEJSKOŚć JAKO OBCOŚć
}

\section{Wprowadzenie}

pozycja „swój-obcy” jest obecna w myśli socjologicznej i etno-
graficznej od dawna. Ze względu na moje zainteresowania
i doświadczenie zawodowe bliższa jest mi myśl socjologiczna, do niej więc będę nawiązywać przede wszystkim. Interesował się nią G. Simmel, W. G. Sumner, twórca skali do badania uprzedzeń i dystansów społecznych E. S. Bogardus. Wśród polskich prekursorów można wymienić Ludwika Gumplowicza oraz krytykującego jego koncepcję Floriana Znanieckiego ${ }^{1}$, J. S. Bystronia i J. Obrębskiego. Antagonizm wobec obcych, uznany przez F. Znanieckiego za „zagadnienie oklepane”, którym zajmowano się od "tysięcy lat" ${ }^{2}$ był przedstawiany jako przejaw „egoizmu społecznego" i, jak wówczas sądzono, wynikał z instynktu samozachowawczego społeczeństw pierwotnych. Umożliwiał identyfikację „swoich” i ochronę interesów własnej grupy. Podział „swój-obcy” i wynikające zeń myślenie w kategoriach "my-oni”, in-group i out-group socjologowie uznają za podstawę i wskaźnik kształtującego się poczucia odrębności i budowania tożsamości zbiorowej, które towarzyszy integracji grupy społecznej. Wobec „swoich” jesteśmy solidarni, lojalni i darzymy ich zaufaniem, wobec „obcych” zachowujemy dystans i odnosimy się nieufnie.

${ }^{1}$ F. Znaniecki, Studia nad antagonizmem do obcych, [w:] tegoż, Współczesne narody. Dodatek, tłumaczenie Z. Dulczewski, Wydawnictwo Naukowe PWN, Warszawa 1990, s. 265-358.

2 Tamże, s. 269. 
Przykłady zaczerpnięte z prac Gumplowicza, Simmla i innych współczesnych Znaniecki określił wspólnym mianem problematyzacji przyrodniczej, jaka, jego zdaniem, przeważa w psychologii. Przeciwstawił jej koncepcje socjologiczne, zgodnie z którymi za obcych wobec danej jednostki uważa się tych, których nie łączy z nią żadna więź społeczna, czyli nie przynależą do tej samej grupy społecznej, nie ma z nimi styczności, bądź którzy się znacznie od niej różnią biologicznie i/lub kulturowo ${ }^{3}$. Przy czym według Znanieckiego brak jest jakichkolwiek obiektywnych właściwości, do których mógłby odwołać się badacz wyznaczając krąg obcych wobec danej grupy lub jednostki. Są nimi ci, których jednostka lub grupa doświadcza jako obcych. W zaproponowanym przez F. Znanieckiego ujęciu problematyki akcent został przeniesiony na kształtowanie się postaw wobec obcych, co wymaga odwołania się do aktualnego doświadczenia, czynności i styczności społecznych. Problem nie polega na udzieleniu odpowiedzi, ,jacy ludzie są obcy w odniesieniu do oznaczonej jednostki lub gromady”, lecz „w jakich warunkach dani ludzie są obcy w odniesieniu do oznaczonej jednostki lub gromady?"4.

Do koncepcji Znanieckiego nawiązał S. Węglarz w pracy Chłopi jako "obcy". Prolegomena ${ }^{5}$, analizując obrazy chłopstwa obecne w pracach etnografów i antropologów kultury, składających się na polską tradycję ujmowania zjawiska. Jej istotnym elementem jest mityzacja obcego i dyskursu na jego temat, co dodatkowo utrudnia poznanie zjawiska.

Opozycja „swój-obcy” była i jest obecna w pracach antropologów kultury, dla których kategorie te stanowią ważne narzędzie opisu, wykorzystywane i użyteczne także w odniesieniu do rzeczywistości wiejskiej. 0 jej wprowadzenie do opisu wsi apeluje także Szanowna Jubilatka, której niniejszy tom jest dedykowany, co dodatkowo czyni zasadnym jej przywołanie w niniejszym tekście i podjęcie takiego tematu ${ }^{6}$.

Wraz z rozwojem społecznym, któremu towarzyszy różnicowanie się społeczeństw ewoluował też stosunek do obcych, wobec których kształtuje się raczej postawa akceptacji i tolerancji w miejsce wrogości i dystansu.

3 Tamże, s. 275, 292.

${ }^{4}$ Tamże, s. 292.

5 S. Węglarz, Chłopi jako „obcy”. Prolegomena, [w:] Pożegnanie paradygmatu? Etnologia wobec współczesności, pod red. W. J. Burszty i J. Damrosza, Instytut Kultury, Warszawa 1994, s. 78-101.

${ }^{6}$ M. Wieruszewska, Wieś w oczach antropologów, [w:] Wieś jako przedmiot badań naukowych na poczq̨tku XXI wieku, pod red. M. Halamskiej, Wydawnictwo Naukowe Scholar, Warszawa 2011, s. 169-186. 
Współcześni socjologowie odwołują się do tej opozycji niezbyt często, głównie w kontekście wykluczenia społecznego, analiz zróżnicowań etnicznych i funkcjonowania grup mniejszościowych ${ }^{7}$.

Trudno bowiem zakładać, że współcześni mieszkańcy wsi, coraz lepiej wykształceni, migrujący w poszukiwaniu pracy i włączeni w szerszy obieg kultury poprzez system edukacji traktują nadal świat zewnętrzny wobec wsi jako „obcy, groźny orbis exterior”. . Było to i jest uznawane za przejaw myślenia mitycznego, obecnego w kulturze ludowej. Gotowa byłabym twierdzić, że to raczej świat zewnętrzny jest nadal skłonny do takiego postrzegania i traktowania wsi, jakby nie zauważając lub nie akceptując dokonujących się w przestrzeni wiejskiej przemian i stosując do jej opisu kategorie odnoszące się do innej rzeczywistości społecznej.

\section{Kategorie „wieś” i „wiejskość”}

Słowo wyjaśnienia odnośnie kategorii „wieś” i „wiejskość”. Okoliczności zastąpienia rzeczownika przymiotnikiem przeanalizowała szczegółowo m.in. M. Halamska9 . Kategorie te nie są współcześnie postrzegane jedynie jako przestrzenie geofizyczne, rozumiane jako odrębny typ lokalności, utożsamiany z „krajem za miastem”. Funkcjonują także jako społeczne reprezentacje, pozbawione konotacji terytorialnych. Co więcej, te społeczne reprezentacje „wiejskości” (rurality) stają się coraz bardziej odległe od fizycznych cech przestrzeni wiejskiej, którą reprezentują ${ }^{10}$. Społeczne reprezentacje wiejskości oznaczają w tym wypadku pewne struktury myślowe, funkcjonujące jako ukryte narracje, będące strukturami poznawczymi, które obejmują zarówno konkretne miejsca, jak i abstrakcyjne pojęcia. Kategorie te nie mają jedynie charakteru empirycznego bądź opisowego, lecz stanowią zbiór znaczeń, które w dyskursie publicznym są przypisywane przestrzeni wiejskiej i z nią utożsamiane ${ }^{11}$. Szerzej przedstawiłam ten problem w innym tekście ${ }^{12}$.

${ }^{7}$ Np. Dyskursy ubóstwa i wykluczenia społecznego, pod red. E. Tarkowskiej, Wydawnictwo IFiS PAN, Warszawa 2013.

${ }^{8}$ M. Wieruszewska, dz. cyt., s. 182.

9 M. Halamska, Wiejskość jako kategoria socjologiczna, „Wieś i Rolnictwo” 2011, nr 1, s. 37-54.

${ }^{10}$ K. Halfacree, Rural Space: constructing a three-fold architecture, [w:] Hanbook of Rural Studies, pod red. P. Clocke, T. Marsden, P. H. Mooney, Sage Publications, London-Thousands Oaks-New Delhi 2006, s. 44-62.

11 Tamże, s. 47.

${ }^{12}$ H. Podedworna, Wiejskość wyzwolona. Nowa konceptualizacja przestrzeni wiejskiej, „Roczniki Socjologii Wsi” t. 29, 2010, s. 7-24. 
W myśleniu postmodernistycznym, w którym mamy do czynienia ze społecznym konstruowaniem wiejskości podkreśla się znaczenie kultury w definiowaniu różnic społeczno-przestrzennych. Z tej perspektywy dla rozumienia wiejskości jest ważna fascynacja specyficznymi wartościami, które lokuje się w przestrzeni wiejskiej i przypisuje wiejskiemu stylowi życia. Wartości te wyraża wyidealizowana wizja wsi i przestrzeni wiejskiej, która jest konstruowana w toku interakcji różnych aktorów społecznych. Zawiera ona konstrukty społeczno-kulturowe wiejskości i przyrody, będące ważnym składnikiem reprodukcji tej przestrzeni oraz jej wyobrażenia i rozumienia w wymiarze geograficznym ${ }^{13}$. Praktyki społeczne, które umożliwiają społeczny proces jej wytwarzania i reprodukowania mogą być badane zarówno z perspektywy zewnętrznej, która pozwala wychwycić ich „strukturację, odwołując się do kategorii A. Giddensa, jak i z perspektywy wewnętrznej, która pozwala rejestrować różnice między nimi, ich tożsamość i społeczne zakorzenienie ${ }^{14}$. Te społeczne konstrukcje zawierają także kategorię „inności”, „obcości”, które nie tyle reprezentują dziś wrogi orbis exterior obecny w kulturze ludowej, co podkreślają i eksponują różnice, w sytuacji ich realnego zaniku i wykluczają ze wspólnoty „swoich”. Warto więc pokusić się o podjęcie próby odpowiedzi na pytanie, jakie miejsce we współczesnych społecznych konstrukcjach „wsi” i „wiejskości” zajmuje kategoria „obcość"?

\section{Kategoria „obcość" w badaniach wsi}

Można mówić o dwojakim występowaniu kategorii „obcość” w kontekście problematyki wiejskiej, jako kategorii jawnej, bądź ukrytej. Pierwsza jest używana wówczas, gdy chce się zaakcentować i podkreślić różnice między tym, co wiejskie a tym, co występuje na zewnątrz wsi, druga funkcjonuje jako głęboko ukryta struktura poznawcza, wykorzystywana przez świadomość zbiorową do stygmatyzowania, stereotypizacji, kreowania pejoratywnych obrazów i negatywnych ocen. Mimo dokonujących się przemian społecznych sposób postrzegania wsi, jej mieszkańców i dziedzictwa wiejskiego oraz stosunek do tego dziedzictwa manifestowany w wielu aktualnych wypowiedziach zarówno przedstawicieli elit opiniotwórczych, jak i pozawiejską

${ }^{13} \mathrm{Ph}$. Macnaghten, J. Urry, Alternatywne przyrody. Nowe myślenie o przyrodzie i społeczeństwie, tłum. B. Baran, Wydawnictwo Naukowe SCHOLAR, Warszawa 2005.

${ }_{14}$ P. Cloke, Conceptualizing Rurality, [w:] Hanbook of Rural Studies, s. 21. 
część społeczeństwa polskiego nacechowany jest dystansem, a niekiedy nawet wrogością. W Polsce, kraju o wiejskim rodowodzie wszystko co wiejskie, wszelkie dziedzictwo wiejskie często bywa traktowane z perspektywy obcości. Zadziwia, że w społeczeństwie niezbyt wyraźnych różnic regionalnych, słabo zaznaczonych zróżnicowań w wymiarze kultury i etniczności znaleziono „obcych” wśród „swoich”, czyli wśród mieszkańców „kraju za miastem", którym świadomość społeczna zwykła nadal przypisywać tożsamość chłopską, chociaż oni sami mogą nie mieć żadnych jej elementów.

Można zasadnie twierdzić, że lęk przed obcym nie stanowi już cechy wyróżniającej mieszkańców wsi, przynajmniej w odniesieniu do społeczeństw rozwiniętych. Jeżeli za reprezentanta „obcych” uznać m.in. socjologa realizującego badania na wsi, to interesujące wskaźniki takich zachowań podaje A. Hańcza ${ }^{15}$, stwierdzając, że na wsi występuje mniejszy odsetek odmów udzielania wywiadów, co oznaczałoby, że relacja badacz-badany jest traktowana przez mieszkańców wsi w kategoriach podmiotowych, z większą ufnością i zaciekawieniem. Wraz z przełamywaniem izolacji lokalnej nieufność wobec obcych zanika, podobnie jak różnicowanie norm społecznych zależnie od tego, czy partnerem interakcji jest „swój”, czy „obcy”, którym współcześnie może być przybysz z miasta, który kupił działkę i wybudował dom w sąsiedztwie. Istniejące różnice kulturowe między mieszkańcami wsi i miasta nie są obecnie tak duże, aby wykluczały wzajemne kontakty, chociaż poznawanie się i akceptacja wymagają czasu. Można powiedzieć, że dawna nieufność ustępuje przed zaciekawieniem i nawiązywaniem styczności, głównie na płaszczyźnie ekonomicznej.

G. Simmel w eseju Obcy połączył kategorię obcości z wędrowaniem, które wyraża brak związku z konkretną przestrzenią oraz z trwałym przywiązaniem do tejże przestrzeni. Pisząc, że „socjologiczna forma „obcości” stanowi w pewnej mierze syntezę obydwóch tych określeń” oraz, że „(...) oddalenie w obrębie stosunku oznacza, że osoba bliska jest daleko, obcość zaś, że blisko znajduje się osoba daleka"16. Podobnie jak cudzoziemiec w odczuciu innych pozostaje „osobą bez własnego miejsca”, tak długo, jak postrzegany jest jako obcy, tak elementy wiejskiego dziedzictwa nie znajdują należnego im miejsca w polskiej kulturze współczesnej, traktującej je często

15 A. Hańcza, „Swoi” i „obcy” w badaniach na wsi, „Kultura i Społeczeństwo” 1996, nr 1, s. 29-45.

16 G. Simmel, Obcy, [w:] tegoż, Socjologia, tłumaczenie M.Łukasiewicz, Wydawnictwo Naukowe PWN, Warszawa 2005, s. 300. 
z dystansu i z perspektywy stereotypowych przekonań. Źródłem obcości według Simmla jest zarówno niezrozumienie jak i wykluczanie z góry ze wspólnoty, która jest budowana na pewnych podstawach ogólnych, umożliwiających łączenie różnych kategorii. Można zauważyć, że temu, co wiejskie odmawia się miejsca, prawa do obecności w kulturze współczesnej, niejako na mocy definicji, która zakłada brak właściwości pozytywnych. Traktuje się więc elementy dziedzictwa wiejskiego jako obce, co uzasadnia wykluczanie ich z szerszej wspólnoty. Jak pisze Simmel: „Dlatego też obcy - to dla nas nie poszczególne jednostki, ale pewna kategoria ludzi o charakterze ogólnym"17. Można sądzić, że z podobnym uogólniającym zabiegiem myślowym mamy do czynienia w myśleniu o wsi, jej mieszkańcach i dziedzictwie. Pozycja społeczna obcego jest specyficzna, zawiera pewną mieszaninę bliskości i dystansu. Kształtuje to specyficzną formę stosunku wobec obcego.

Wcześniej to, co wiejskie w kulturze reprezentowało idyllę, ucieleśniało tęsknoty za utraconym rajem, który był zbudowany na fundamencie związku człowieka z przyrodą, przywiązaniu do ziemi i do wspólnoty, pisze P. Cloke 18, mając na myśli epokę industrialną. Tak rozumiana wiejskość wyrażała odwieczne tęsknoty człowieka za otwartą przestrzenią i wolnością, a więc wartościami, które cenił wysoko pozbawiony ich mieszkaniec wczesnoprzemysłowego miasta, w którym brak było wielu współczesnych udogodnień cywilizacyjnych. W przeciwieństwie do różnicujących się miast, wieś długo pozostawała homogeniczna, nieskażona obecnością mieszkańców wywodzących się z innych grup etnicznych i kultur. Społeczne definicje wiejskości były więc wykorzystywane do podtrzymywania tej kulturowej idylli.

Zmiana w definiowaniu i postrzeganiu wiejskości, jaka nastąpiła w społeczeństwie ponowoczesnym wiąże się z powstaniem jej nowych metanarracji. Wiejskość jest przedstawiana jako społecznie konstruowana, zróżnicowana, obejmująca wiele odmiennych obrazów. Tworzą ją zarówno obrazy rozwijających się przestrzeni podmiejskich, jak i pogrążonych w stagnacji przestrzeni peryferyjnych; zróżnicowane wiejskie przestrzenie regionalne, gdzie występują żywe lub nie tradycje kulturowe; przestrzenie związane z produkcją rolniczą oraz pełniące jedynie funkcje rezydencjonalne. Opisane różne obrazy wiejskości charakteryzują się odmienną wewnętrzną

17 Tamże, s. 304.

18 P. Cloke, Rurality and racialized others: out of place in the countryside, [w:] Handbook of Rural Studies, s. 379-387. 
dynamiką, którą kształtuje kontekst zewnętrzny wobec przestrzeni wiejskiej, związany z globalną gospodarką, kulturą mobilności, komercjalizacją miejsca. Efektem tych różnych wewnętrznych dynamik jest zanik wiejskości, upodobnienie jej do miasta, urbanizacja wsi i „ucieczka z miasta” (counterurbanisation).

Obrazy wiejskości zawierają także dystopie społeczne, będące przestrogą, przedstawiające dalekie od idylli złe życie, obrazy klęsk i zagrożeń ekologicznych, groźnych nie tylko dla człowieka, ale również dla innych istot żywych. Katastroficzne skutki epidemii chorób zwierzęcych, jak BSE czy ptasia grypa, które unicestwiały ogromne populacje obserwowane i przedstawiane $\mathrm{w}$ mediach miały miejsce $\mathrm{w}$ przestrzeni wiejskiej. Podobnie jak odkrywane ostatnio w Polsce afery dotyczące negatywnych zjawisk w sferze produkcji żywności, która stała się groźna dla człowieka, dyskusje wokół stosowania GMO oraz uboju rytualnego, to wszystko przykłady obrazów przestrzeni wiejskich, które dalekie są od wiejskiej idylli.

Inne obrazy przestrzeni wiejskiej, pozbawione elementów idylli przedstawiane są jako miejsce występowania wielu problemów społecznych, takich jak bezrobocie, ubóstwo, zagrożenia dla środowiska przyrodniczego, okrucieństwa wobec zwierząt. Takie obrazy wiejskości konstruowane są z dala od wiejskiej przestrzeni geograficznej, ucieleśniają wykluczenie społeczne, marginalizację, słabo tolerowane peryferie, „nie nasz świat” ${ }^{19}$, który można traktować z dystansem, jako obcy właśnie.

Należy podkreślić, że znaczenia odnoszące się do świata wiejskiego nie zostały zaczerpnięte wprost z zaobserwowanych różnic między jednostkami i organizacjami. Zostały one społecznie skonstruowane w taki sposób, że wytworzone konstrukty społeczne pozostają bez związku z funkcjonalną przestrzenią wiejską w rozumieniu geograficznym, stając się tworem swoistym, hyper-rzeczywistością ${ }^{20}$, towarem przygotowanym na sprzedaż, który może mieć wyłącznie postać wirtualną, bądź marką handlową (rural brand). Zdaniem wielu badaczy (m.in. Cloke) przyjęcie perspektywy konstruktywistycznej spowodowało zwrot w naukach społecznych polegający na zaniechaniu badań analizujących zmiany społeczno-ekonomiczne zachodzące w realnej przestrzeni wiejskiej i ograniczenie się do badania

19 Tegoż, Rurality and otherness, [w:] Handbook of Rural Studies, s. 447-456.

20 Tegoż, Countrybackwater to virtual village? Rural Studies and „the Cultural Turn”, “Journal of Rural Studies" 1997, nr 4 (13), s. 367-375. 
manifestacji wiejskości w sferze kultury, wzorów konsumpcji, znaczeń, symboli, itp.

We współczesnym dyskursie są obecne różne narracje wiejskości, wyrażające dwa odmienne sposoby postrzegania świata wiejskiego. W jednej narracji, określanej jako sielankowa, eksponuje się wysoko społecznie wartościowane elementy wiejskiego stylu życia, takie jak możliwość bliskiego kontaktu z przyrodą, brak zagrożeń ekologicznych, brak uciążliwości życia w wielkim mieście i różnorodne doznania estetyczne, jakich to obcowanie z przyrodą dostarcza. Druga narracja, pro-modernistyczna eksponuje zapóźnienie, niedorozwój, zastój i towarzyszące im negatywne zjawiska społeczne, takie jak bieda, bezrobocie, braki infrastruktury technicznej oraz ograniczony dostęp do usług publicznych. Pomiędzy tymi krańcowymi obrazami można skonstruować wiele różnych obrazów pośrednich, wśród których znajdzie się także obraz wsi jako oferenta wyższej jakości życia dla wybranych kategorii społecznych, takich jak twórcy, emeryci, osoby niepełnosprawne.

Definicje „wiejskości” występujące w literaturze przedmiotu można uporządkować w następujące kategorie:

1. definicje opisowe, charakteryzujące różne cechy świata wiejskiego;

2. dychotomie wieś-miasto, taki sposób definiowania podkreśla występowanie różnic, zacierając związki i podobieństwa;

3. typologie konstruowane w ramach różnych jednostek geograficznych;

4. wskaźniki i indeksy pozwalające mierzyć różny stopień wiejskości danego obszaru.

Ważnym źródłem przekształcania i reprodukowania społecznych reprezentacji wiejskości w krajach UE jest zdaniem J. Graya wspólna polityka rolna i polityka rozwoju regionalnego ${ }^{21}$. To w wyniku realizowania ich celów kształtuje się zarówno przestrzeń geofizyczną obszarów wiejskich, jak i jej obrazy funkcjonujące w dyskursie społecznym. Programy tych polityk i rozdzielane w ich ramach środki finansowe, które wykorzystują zarówno rolnicy jak i władze lokalne podtrzymują funkcjonowanie odrębnej przestrzeni wiejskiej, rozumianej jako krajobraz, przestrzeń geofizyczna i środowisko

${ }^{21} \mathrm{~J}$. Gray, The Common Agricultural Policy and the Re-invetion of the Rural in the European Community, "Sociologia Ruralis" 2000, z. 1 (40), s. 30-52. 
społeczne, które dotychczas utożsamiano z rolnictwem i produkcją żywności. Na potrzeby wspólnej polityki rolnej UE i polityki rozwoju regionalnego definiuje się obszary wiejskie w kategoriach zapóźnień i trudności rozwojowych, co otwiera dostęp i umożliwia wykorzystywanie specjalnych subsydiów i funduszy strukturalnych. Funkcjonujący w UE mechanizm subsydiowania produkcji rolnej jest wykorzystywany przez rolników. Umożliwia im kontynuowanie odpowiednich praktyk produkcyjnych i reprodukcję rolniczej przestrzeni wiejskiej w konkretnym miejscu, w zgodzie z dyrektywami i w odpowiedzi na wymogi i cele wspólnej polityki rolnej.

Mechanizm ten ukształtował nowy społeczny obraz wiejskości. Zdaniem Greya $^{22}$ wiejskość z nieuchwytnej, niezależnej, określanej przez specyficzny kontekst narodowy improwizowanej praktyki socjo-lingwistycznej stała się zobiektywizowaną, publicznie zauważalną, sformalizowaną i zgeneralizowaną w granicach UE reprezentacją społeczną. Taki obraz wiejskości przyniósł też pewne korzyści polityczne. Polegały one na tym, że każde państwo członkowskie mogło interpretować kategorię wiejskości zgodnie z własnym narodowym interesem. Chociaż przyjęte na początku zasady wspólnej polityki rolnej odnosiły się głównie do sfery ekonomicznej - jednolity rynek, zniesienie ceł wewnętrznych i wprowadzenie ceł zewnętrznych w handlu produktami rolnymi oraz wspólne ceny na artykuły rolne, oddziałały one na praktyki produkcyjne, w wyniku których ukształtowała się współczesna przestrzeń wiejska w przeważającej części Europy.

\section{Podsumowanie}

Postrzeganie, definiowanie i traktowanie wiejskości zależy od miejsca jakie zajmuje w kulturze danego społeczeństwa, od znaczenia wsi i rolnictwa w życiu społecznym i gospodarczym. W większości krajów europejskich definiowanie i postrzeganie wiejskości zawiera jakieś elementy tradycji chłopskiej, rolnictwa i kultury ludowej. W społeczeństwach ponowoczesnych obecność tych treści kurczy się dramatycznie. Można zastanawiać się, $\mathrm{w}$ jakim stopniu te nowe elementy i treści spowodują zmianę postawy wobec dziedzictwa wiejskiego. Nie we wszystkich krajach europejskich są one nacechowane w takim stopniu obcością i dystansem, jak ma to miejsce w Polsce. W niektórych, przykładem mogą być Austria, Francja, dziedzictwo wiejskie jest waloryzowane zdecydowanie pozytywnie.

\footnotetext{
${ }^{22}$ Tamże, s. 33.
} 


\section{BIBLIOGRAFIA}

- Cloke P., Conceptualizing Rurality, [w:] Hanbook of Rural Studies, pod red. P. Clocke, T. Marsden, P. H. Mooney, Sage Publications, London-Thousands Oaks-New Delhi 2006.

- Cloke P., Countrybackwater to virtual village? Rural Studies and "the Cultural Turn", "Journal of Rural Studies" 1997, nr 4 (13).

- Cloke P., Rurality and otherness, [w:] Hanbook of Rural Studies, pod red. P. Clocke, T. Marsden, P. H. Mooney, Sage Publications, London-Thousands Oaks-New Delhi 2006.

- Cloke P., Rurality and racialized others: out of place in the countryside, [w:] Hanbook of Rural Studies, pod red. P. Clocke, T. Marsden, P. H. Mooney, Sage Publications, London -Thousands Oaks-New Delhi 2006.

- Dyskursy ubóstwa i wykluczenia społecznego, pod red. E. Tarkowskiej, Wydawnictwo IFiS PAN, Warszawa 2013.

- Gray J., The Common Agricultural Policy and the Re-invetion of the Rural in the European Community, "Sociologia Ruralis" 2000, z. 1 (40).

- Halamska M., Wiejskość jako kategoria socjologiczna, „Wieś i Rolnictwo” 2011, nr 1.

- Halfacree K., Rural Space: constructing a three-fold architecture, [w:] Hanbook of Rural Studies, pod red. P. Clocke, T. Marsden, P. H. Mooney, Sage Publications, London -Thousands Oaks-New Delhi 2006.

- Hańcza A., „Swoi” $i$ „obcy” w badaniach na wsi, „Kultura i Społeczeństwo” 1996, nr 1.

- Macnaghten Ph., Urry J., Alternatywne przyrody. Nowe myślenie o przyrodzie i społeczeństwie, tłum. B. Baran, Wydawnictwo Naukowe SCHOLAR, Warszawa 2005.

- Podedworna H., Wiejskość wyzwolona. Nowa konceptualizacja przestrzeni wiejskiej, „Roczniki Socjologii Wsi” t. 29, 2010.

- Simmel G., Obcy, [w:] tegoż, Socjologia, tłumaczenie M. Łukasiewicz, Wydawnictwo Naukowe PWN, Warszawa 2005.

- Węglarz S., Chłopi jako „obcy”. Prolegomena, [w:] Pożegnanie paradygmatu? Etnologia wobec współczesności, pod red. W. J. Burszty i J. Damrosza, Instytut Kultury, Warszawa 1994.

- Wieruszewska M., Wieś w oczach antropologów, [w:] Wieś jako przedmiot badań naukowych na początku XXI wieku, pod red. M. Halamskiej, Wydawnictwo Naukowe Scholar, Warszawa 2011.

- Znaniecki F., Studia nad antagonizmem do obcych, [w:] tegoż, Współczesne narody. Dodatek, tłumaczenie Z. Dulczewski, Wydawnictwo Naukowe PWN, Warszawa 1990. 


\section{RUSTICITY AS OTHERNESS}

This article is an attempt at an analysis of the meaning of the category of rurality presented from the perspective of "otherness". The author begins from a sociological formulation of the notional opposition "we"-"others". She has used the concept of F. Znaniecki, explaining the antagonism towards others, and the concept of G. Simmel, as well as their application in the works of Polish researchers of the rural culture. The author has reviewed the meanings of the category of "countryside" and "rurality", which in the postmodern era are constructed socially and refer more to the sphere of culture rather than to the description of real geographical space. As a result, in the social discourse there function various narrations of rurality from a pastoral narration, presenting the countryside as rural idyll, to the postmodern narrations, exposing the backwardness and underdevelopment of the countryside. The category of "otherness" appears in the context of rural problems as an overt or hidden category. The former is used to emphasize the differences between the rural and the non-rural world, the latter functions as a latent cognitive structure.

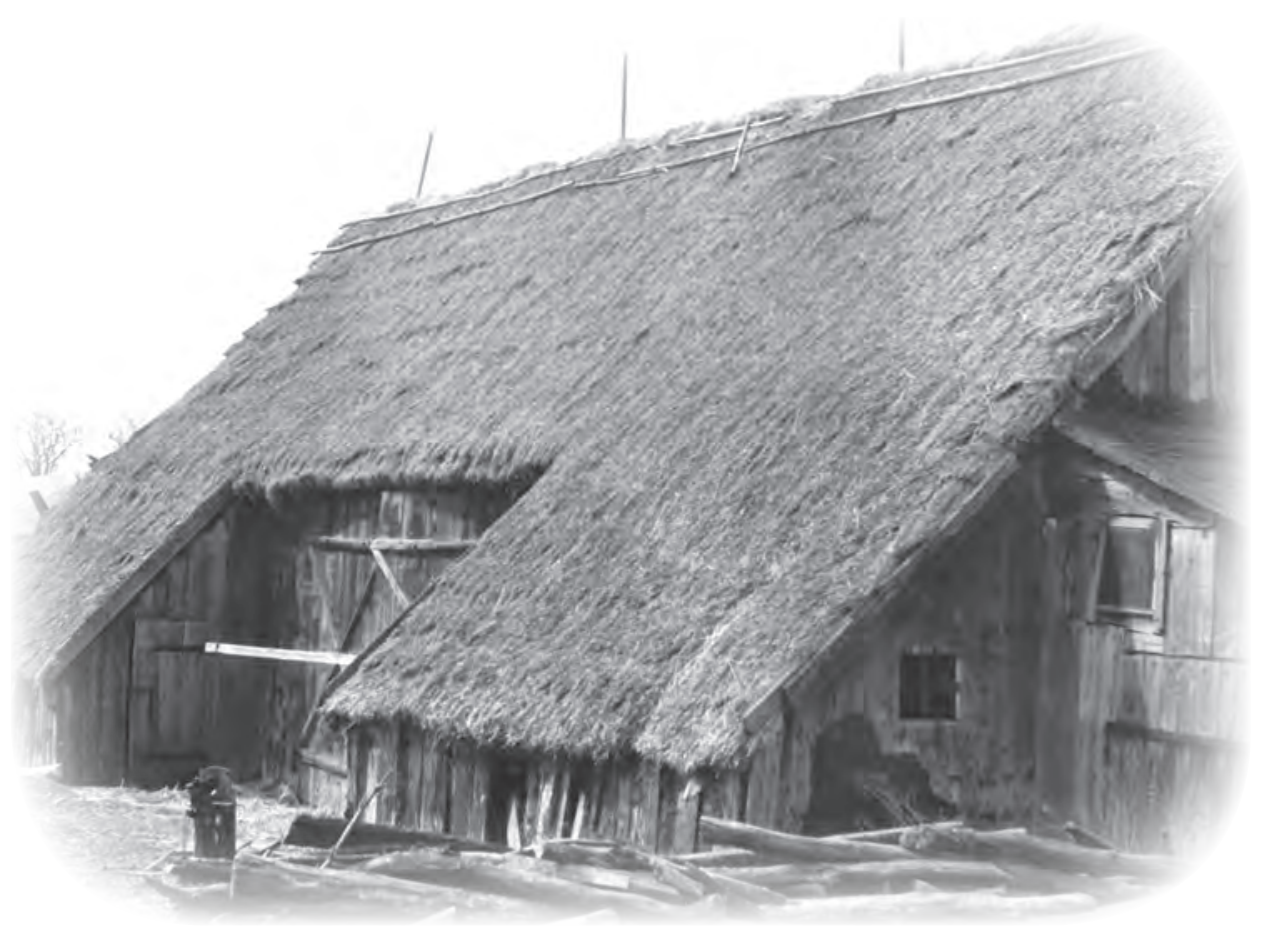

